\title{
Lars Levi Sunna: \\ Crafting a Sámi Presence in the Swedish State Church ${ }^{1}$
}

\author{
THOMAS A. DUBOIS \\ University of Wisconsin-Madison
}

\begin{abstract}
The article explores the intertwined religious and artistic viewpoints of contemporary Sámi artist Lars Levi Sunna of Kiruna, Sweden. Sunna self-consciously situates his artwork within a personal and familial history that centers around traditional Sámi livelihoods and the practice of handicraft (duodji). Through his duodji-inspired pictorial art and art installations, Sunna chronicles a personal exploration that involved learning about his people's pre-Christian religious traditions and consciously making a place for them within his life and work, while maintaining his identity as a Laestadian Christian.

Keywords: Sámi, handicraft, duodji, Laestadianism, Lars Levi Sunna, shamanism
\end{abstract}

Lars Levi Sunna stands as an innovative modern artist whose work originated in the thriving enterprise of contemporary Sámi art handicraft, a set of traditionally-informed artistic norms, forms, and techniques that are commonly referred to by practitioners and art connoisseurs alike through the North Sámi term duodji. Generally employing some combination of traditional materials, aesthetic notions, and forms, contemporary duodji craftsmen seek to produce works that strongly evoke a distinctive Sámi heritage, rooted in the common daily activities of the traditional past: especially hunting, migration, and reindeer husbandry. Sámi knives of steel, antler and wood, bags or boxes of wood, root, or leather, and implements such as bone salt containers or wooden milk pails, recall a life spent on the move, enmeshed in an unending seasonal cycle and surrounded by an aesthetic sense strongly informed by the values of functionality and durability. Contemporary duodji owes much to the visionary efforts of turn-of-the-century

1 An earlier version of this paper was presented at the Ninety-eighth Annual Meeting of the Society for the Advancement of Scandinavian Study, held in Fairbanks, Alaska, 13-15 March, 2008. I am grateful to the conference participants, especially Mikael Svonni, Krister Stoor, Andrea Amft, and Coppélie Cocq for their helpful comments and assistance in preparing this work. I also thank Mr. Lars Levi Sunna for his ready and enthusiastic assistance in my research. 
craftsmen and educators who promoted instruction in traditional arts as a component of Sámi schooling in areas with significant Sámi populations (Lehtola 2004, 114-15). Today, duodji represents a meaningful and often lucrative livelihood for hundreds of Sámi artists, who sell works not only to other self-identifying Sámi community members (some 80,000 people in Norway, Sweden, Finland, Russia and abroad), but also to a burgeoning non-Sámi clientele of thousands, both within the Nordic region and beyond.

Amid this lively and important enterprise, Lars Levi Sunna has emerged as a remarkable innovator, not only in his penchant for creating works that depart markedly from the ideal of traditional functionality, but also in his recurrent and sometimes provocative exploration of the spiritual worldview of his culture's pre-Christian past. A committed Christian raised within the Laestadian community of Kiruna (Giron) in northern Sweden, Lars Levi Sunna nonetheless produces art that forcibly unites the forms and materials of duodji with a pre-Christian belief system, transforming them into emblems of his culture's former and lingering religious alterity. In the case of artworks produced specifically for use within Christian worship contexts, Sunna's union of duodji aesthetic and pre-Christian themes stand as a resolute and undeniable reminder of the cultural rupture of the Sámi missionary experience, underscoring the conflicts and injustices of the Christianization process for a viewership of both Sámi Christians and clergy, Sámi and non-Sámi alike.

In this paper, I discuss four of Sunna's largest and best known works two for use in secular spaces, two intended for display within churches - to explore the means by which they unite artistic traditions, communal history and personal identity into complex wholes that manifest both continuity with and enforced disjunction from an idealized worldview of the past. On a fundamental level, Lars Levi Sunna's works - and his commentary upon them - can be viewed as spirited meditations on the process of Christianization endured or achieved by his community over the past half millennium. In the following, then, I present first an overview of Sunna's life and career, followed by a description of the four projects that epitomize his approach to his culture's religious history. I close by relating Sunna's works and views to those of other indigenous communities confronting the historical legacy of forced conversion. Particularly, I hope to shed light on communities that acknowledge past injustice while simultaneously refusing to reject outright the incurring or usurping religion, to explore the conflicts and difficulties inherent in this complex stance. 


\section{Growing into an Artist}

Lars Levi Sunna was born in 1944 in Årosjokk, near Kiruna, Sweden. Sunna's parents were Laestadian Christians who had formerly made their living off reindeer herding. Sometime during the 1930s, before Lars Levi's birth, a severe winter devastated his parents' herd and forced them to change livelihoods. They became small farmers who raised cattle, goats and sheep and practiced handicraft. By the 1950s, the family had begun to produce handicraft for sale, offering goods to travelers on the Nordkalott highway from Kiruna to Narvik or at the Narvik train station. Lars Levi learned craft as part of daily life, with little differentiation between workplace and home. As Lars Levi relates:

Very early on I came into contact with craft...it was part of my home life...a part of daily life so that there was no workshop outside of the home... a great deal was produced in the home environment and one grows into being part of that oneself. ${ }^{2}$

Lars Levi learned to carve as a means of earning a little pocket money, and gradually became proficient in a wide range of crafts, something he shared with other siblings, such as his well-known brother Tore Sunna, whose art was among the first pieces of Sámi craft to be selected for inclusion in the collections of the Swedish National Museum.

It was while the family was selling their arts one summer that Lars Levi first heard about noaidi (shamanic) magic. He recalls his first experience of the term noaidi in the following story:

One Sunday we rode down from Björkliden to Abisko...to a hill where many Sámi used to sit and sell goods. I was nine or ten at the time, and there was an old man there too, whose name was Årpus. And it was really beautiful weather and hot summer day. And we who were selling, many of the Sámi sat on their reindeer skins with their stuff they were selling beside them. Many of the people there had really beautiful things, but this Årpus, he had, well you'd have to call it scrap. And all the Norwegians and the Danes and the Germans, and the English-speakers and speakers of various languages, and the French speakers, they all passed him by. But then he disappeared into the bushes and comes back with a big, thick, white reindeer skin on -

2 Unless otherwise indicated, quotations are from my recorded interview of Lars Levi Sunna at Folkets hus, Kiruna, Sweden, September 2005, conducted in Swedish. 
and it's nearly thirty degrees out - and suddenly they go like a swarm of people to him with packs and, they buy up just everything he has! They buy it all, and then the others who were there say, 'He used noaidi arts!' And that was the first time I had contact with the word. [...]

What seems to have struck Lars Levi as particularly significant about this moment was that the adults shared a largely unspoken belief in noaidi magic, a belief which, though stigmatized in their Christian upbringing, still remained operative as a source of explanation for uncanny events. This same realization recurred for Lars Levi later, around the year 1968-69, when as a 25-year old, he had just set up a workshop for himself in the city of Kiruna. A number of older Sámi men had also recently moved to the city from the countryside, and regularly congregated at Sunna's shop in order to use his power tools on projects of their own. Time and again, such elders would tell stories of encounters with possible noaiddit in their communities, or of supernatural events in the locale. One elder, for instance, told Sunna how he had been to an area near Karesuando where they had such big reindeer bulls with such large antlers that the man was afraid to enter the corral with them. He remarked that they were precisely like the animals in a saivo (sájva) herd, and that their antlers would be especially valuable for a craftsman to use. ${ }^{3}$ Sunna took the man's advice and acquired horn from the herd, which proved indeed enormous and thus very useful for his work. Again, Sunna was struck that the old narrators did not separate their beliefs in noaiddit or saivo spirits from their spiritual views as Laestadians. Sunna notes: 'They were all Laestadian Christians and were regulars at the prayer meetings here in Kiruna since childhood [... $]^{\prime}$

The openness and matter-of-fact manner with which Sunna's respected Laestadian elders discussed the pre-Christian beliefs of Sámi people differs markedly from what many people - Sámi and non-Sámi, Laestadian and non-Laestadian - have assumed about Laestadian attitudes toward non-Christian beliefs and practices. The ease with which they bridged the religious gulf between what Lars Levi had regarded as a long past belief system and their own present identities as Christians caused Lars Levi to take a new interest in the old traditions of his people. On reflection, he began to recognize ways that his parents and other adults of the community had imbued their children with a respect for the old religion and its sacred sites without ever speaking of the topic directly. He relates:

3 For discussion of sájva spirits in Sámi religion, see both Bäckman 1975 and Outakoski 1991. 
People didn't really talk about it openly, but as there is contact between parents and children, there is also a communication that can happen, partly even by silence. We could never go to certain islands: we could never take a boat there or we could never light a fire there but rather we treated is as a protected place. And one didn't ask why it was a protected place, rather one simply understood that it was the dwelling place of the dead. If one went by in a boat, one should observe silence and be still. And this [custom] was there even though the most of them [i.e., the adults] were Laestadians and Laestadian preachers had said that this was a demonic belief.

Lars Levi's growing realization of an unspoken respect for the old religion led him in turn to begin to read published accounts of the pre-Christian religious traditions of the Sámi people. He read works by Ernst Manker (e.g., Manker 1938; 1947; 1950) as well as others, and began to take a more detailed interest in the old stories and passing references that old Sámi mentioned to him in their conversations. At first, he contemplated recording these using a tape recorder that he purchased for the purpose, but soon he realized that the presence of a microphone would impede most such communication. A hidden microphone was, in Lars Levi's view, wholly unethical. Perhaps in part in response to this abundance of new learning which he could not otherwise record, as well as his personal desire to somehow incorporate this knowledge into his own identity, Lars Levi began to create images in his art of the supernatural beings and phenomena of the Sámi past. According to Ulf Boström (1998, 77), a crucial turning point came when the young artist, now well-known for his more conventional duodji products, tore his order book to pieces which he threw in the fire. Writes Boström: 'Orders for Sámi craft valued at a half million kronor were transformed in a few moments to smoke and ash.' ${ }^{4}$ He quotes Sunna: 'That was the smartest thing I ever did. All that was nothing at all' (p. 77).

In his overview of contemporary Sámi duodji, Kurt Kihlberg (2003, 71-5) quotes the views of Per-Ola Utsi of Porjus from the 1970s. Utsi contrasted the views and practices of his parents' generation with those of his own:

When I see my parents practicing their handicraft, it is easy for me to say, 'This is real Sámi handicraft.' Not just because they are Sámi who are making classical Sámi objects that have evolved over the centuries. But also because they are making the objects in almost the same way and with the same

4 I have translated quotations from Swedish publications into English. 
thought as their parents. It is an inherited skill which they are practicing and which they in their turn have taught me. (Kihlberg 2003, 71.)

The mark of quality in works produced by this generation thus lies in their evident and largely unconscious continuity with the past, particularly with the worldview and customs of Sámi of earlier eras. On the other hand, Utsi viewed artists of his own generation as not only possessing the right but also the responsibility to adapt the old forms to new uses:

When I sit down to create something I am infected by all the technology of our age, I have acquired other values and my way of thinking is different from my ancestors' way of thinking. Our way of life has changed and thus the old utensils for everyday use have lost their function. If we are to hand on this heritage to coming generations, it is very important for us to utilize the knowledge of our ancestors as the basis of our own handicraft, which of course must become something different to fit into the society of today. (Kihlberg 2003, 71.)

In Utsi's view, modern craft artists are thus far more self-conscious and intentional than their counterparts in earlier generations. They create works that are not simply functional but also emblematic: symbols of a past Sámi way of life and aesthetic.

It was in this context of openness to artistic experimentation that Lars Levi Sunna began to explore duodji that incorporated pre-Christian themes and forms, including noaidi drums, and eventually, sculptural assemblages of the sort described below. While delving into these new artistic experiments, Lars Levi prepared for criticism from two different quarters. On the one hand, he worried that his parents would take offense at his production of works that harkened back to a pre-Christian religiosity so strongly vilified and rejected by many Christians over the past several centuries. On the other hand, particularly as his work moved toward more narrative installations of figurines, he worried that duodji practitioners would regard his art as too great a departure from the ensconced values of functionality and traditionality within the duodji enterprise. According to Sunna, his worries on the first front proved unnecessary, while those on the second were wellfounded. Sunna recounted discussing the growing pre-Christian elements of his art with his mother: 
She stands there and looks out the window, and she said: 'Váldde dat dego dat lea - Take it as it is - ja don boađát oaidnit - and you will come to see.' I started to make sculptures and creations of the ideas I had gotten from Ernst Manker's books and they [i.e., the parents] weren't exactly excited about it but they didn't forbid it either. The responsibility lay in a way with me myself. It was I myself who must seek and figure out how to approach this material. 'Take it as it is and you will come to see.'

In contrast, and despite the enlightened views of Sunna's contemporary Per-Ola Utsi quoted above, Lars Levi experienced strong censure from other duodji artists, who often felt that his work - particularly the sculptural pieces discussed below - no longer represented a true continuity with the handicraft tradition they drew upon for form and technique. 'The works didn't have enough functionality, they said, and without this functionality they were no longer really part of the duodji tradition.' Lars Levi can chuckle now at these pronouncements, but their criticisms were biting and discouraging at the time. Nevertheless, in the fashion of a true artistic innovator, Lars Levi continued his explorations, producing works that are now lauded as significant statements of Sámi identity and as landmarks in the gradual diminution of the once significant barrier between the categories of ' $\mathrm{craft}^{\prime}$ and 'art' in elite Nordic art circles.

\section{'Samisk kultur, tradition och vardag', 1976}

In 1976, at the age of 32, Lars Levi produced an important installation for the Kiruna Stadshuset. His sculpture, entitled 'Samisk kultur, tradition och vardag' [Sámi culture, tradition and daily life], broke new ground in the growing nexus of handicraft and nonfunctional art (Kihlberg 1999, 35). Sunna made use of masur (curly-grained, weeping, or silver birch, Betula pendula), and reindeer antler to create semi-abstract models of Sámi men and women, reindeer, and a bear along with elements of traditional daily life, e.g., a Sámi tent and sled. The bodies of the figurines were finely sanded and rounded in the manner of duodji knife handles or wooden box exteriors. The faces and hands were constructed of inset medallions of reindeer antler, bearing etched details. This combination of wood and bone replicated the norms of duodji decorative box construction, in which curly grained birch and medallions of reindeer antler are common and characteristic elements. In this way, Sunna's figurines look almost like pieces of Sámi duodji that have mysteriously acquired human form and have been captured in the act 


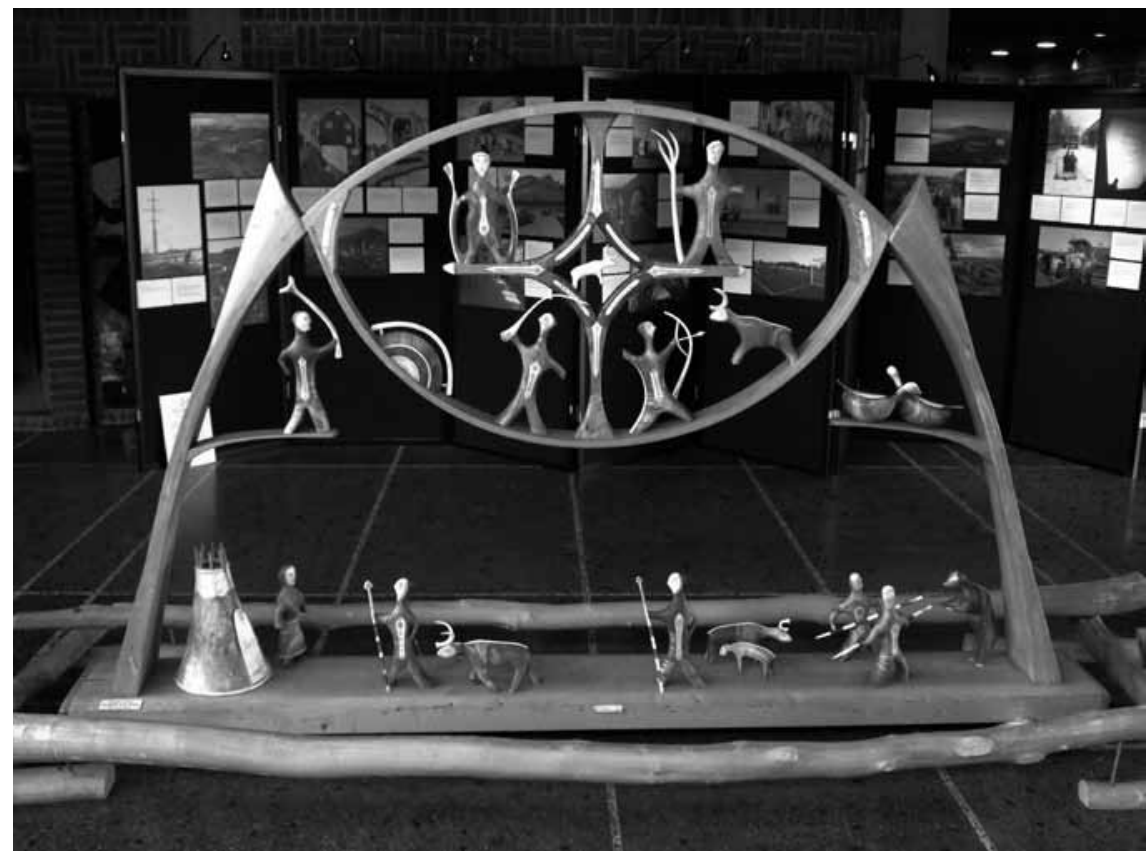

Figure 1. Samisk kultur, tradition, och vardag, 1976. Kiruna Stadshuset. Photo courtesy Mikael Svonni.

of striding across a table or other space. Their body language - stepping confidently, one leg thrust in front of the other, or standing attentively with arms spread wide, represent familiar and nostalgic images of Sámi daily activities, lovingly reduced to the level of near abstraction. According to Sunna, the scene at the base of the assemblage is meant to capture Sámi migration with their reindeer herd, as well as the herders' efforts to guard the calves from hungry predators (Sunna 1998, 83).

Two arching pieces of wood at the outer ends of the assemblage describe a pair of mountains in Sunna's pictorial program. These represent the northern and southern limits of Sápmi, the Sámi homeland, and the interconnected communities of North and South Sámi. Arrayed between the mountain tops and stretching above the entire lower portion of the assemblage, Sunna has created an almond-shaped mandala that recalls the overall form and etched figures of a Sámi shamanic drumhead. ${ }^{5}$ Here, birch and antler figurines replicate or evoke drumhead pictographs as depicted in Manker's seminal

5 For discussion of the importance of the drum in pre-Christian Sámi religious life, see Ahlbäck 1987 and Ahlbäck \& Bergman 1991. 
studies (Manker 1938; 1950), including a rhomboid sun with rays extending in four directions and depictions of deities and mythological figures. Sunna adapts the dark-light gestalt figures of the pre-Christian drumheads in a manner which is immediately recognizable to a viewer with knowledge of pre-Christian Sámi iconography. The deity Bieggolmmái, for instance, is depicted holding two unevenly sized shovels, as in typical drumhead depictions. At the same time that the figurines recall their drumhead prototypes, however, they also render them three-dimensionally, giving them personal facial expressions and fine details that transform them into representations of living beings. The effect of this rendering humanizes the rather abstracted pictographs of ancient Sámi iconography while also infusing them with the positive associations and assumptions of functionality typical of duodji.

Further sculptures inhabit a mediating space between this overarching drum region and the earth below, suggesting contact between the different levels of the cosmos. Here, on what he describes as mountain ledges, Sunna has placed a figurine representing a noaidi as well as two depictions of birds (Sunna 1998, 83). The noaidi thus plays a crucial role in the sculpture, uniting its serene supernatural upper level with the bustling everyday activities depicted on the ground level. In essence, the sculpture is a presentation of the Sámi cosmos, an ancient worldview materialized for the modern viewer.

Sunna's sculptural assemblage proved predictive of the forms he would put forward in later projects. Here we see the artist's creative adaptation of traditional materials and techniques of ornamentation, as well as his tendency to construct artistic wholes out of constellations of discreet, seemingly simple elements. The individual figurines themselves have an unimposing and homespun appearance, belying the remarkable craftsmanship entailed in the production of each. A key element of the work's aesthetic force resides in the union and juxtaposition of these figures within the three interrelating visual fields - ground level, mountain ledge, and sky - ones which depict not only everyday life, but also moments of ceremonial importance and mythic significance. The sculpture as a whole depicts Sámi people enmeshed in a meaningful world characterized by both traditional activities and beliefs, in which the techniques and formal vocabulary of duodji become the very fabric of community and spiritual life. 


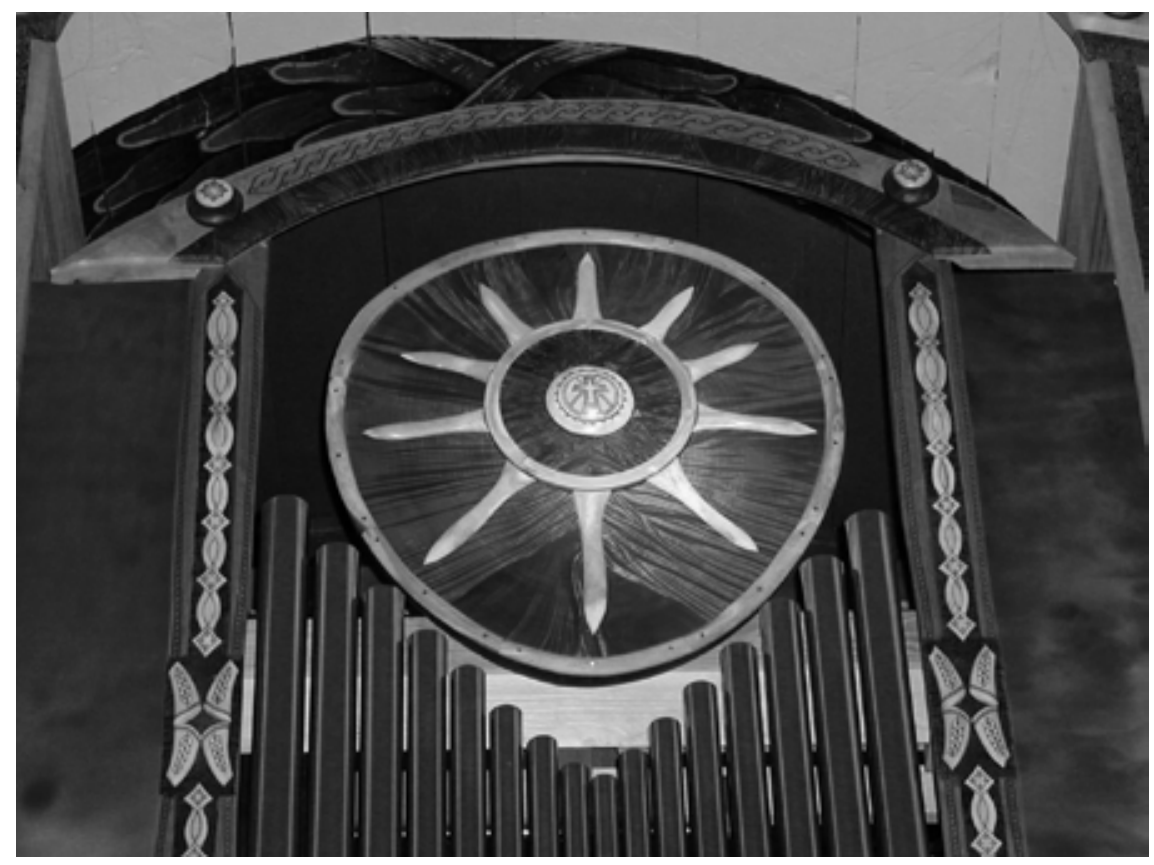

Figure 2. Sun symbol, Organ decoration, Jukkasjärvi Church. Photo courtesy Catarina Grönlund of Grönlunds Orgelbyggeri.

\section{Decorating an Organ, 1997}

In 1997, Sunna collaborated with Grönlunds Orgelbyggeri of Gammelstad, Sweden, to create a distinctively Sámi façade and key decorations for an organ to be housed in the parish church at Jukkasjärvi (Čohkkiras), of the Kiruna municipality, where Sunna serves as a pastoral associate. ${ }^{6}$ This is a church of tremendous importance to local Sámi and one of significance to Laestadians and non-Laestadians alike. Here, an instrument emblematic of the social, musical, and iconographic norms of state Christianity becomes a vehicle for a markedly assertive and confident expression of Sámi identity. As Sunna puts it: 'I couldn't leave my cultural heritage in the vestibule. I must come before God with everything that I am.' (Boström 1998, 81.)

In an article that appeared at the time of the organ's first installation, Ulf Boström $(1998,76)$ suggests that Sunna's iconography is designed as a counterpoint to Bror Hjort's (1894-1968) celebrated altarpiece which

6 I am grateful to Catarina Grönlund of Grönlunds Orgelbyggeri for the photos of the organ included in this article. 
dominates the entire eastern wall of the Jukkasjärvi church. Carved in 1958 of imported teak wood overlaid with bold colors reminiscent of Sámi traditional dress, Hjort's triptych reminds the viewer of the main points and figures in the development of the religious movement within Nordic Lutheranism founded by Lars Levi Læstadius (1800-1861). Læstadius, of Sámi and Swedish heritage, attributed his true conversion to Christ to the earnest testimony of a Sámi woman, depicted prominently in the right-hand panel of the triptych, a Midsummer sun behind her head. The altarpiece's left wing depicts Læstadius condemning the alcohol abuse that plagued Sámi communities during his time, while the central portion of the triptych portrays a suffering Christ, blood dripping from his head to create flowers below.

As Ulf Boström $(1998,76)$ points out, the portion of the church organ visible from the congregation's pews picks up on the spherical sun of Hjort's depiction and transforms it into a blazing sun with long extending rays, reminiscent of shamanic drum depictions. The sun did not only figure as a decoration of noaidi drumheads, however, but was also viewed as an important deity among pre-Christian Sámi, as Lundmark $(1982 ; 1985)$ has discussed. Thus, this image carries profound weight for a Sámi viewer, particularly when placed above the congregation and facing the church's altar. In Sunna's rendering, the blazing sun is engulfed in a birch mandala suggestive of a noaidi drum and ornamented in its center with a raised antler medallion, etched with a cross. The figure thus unites a variety of potent symbols from both the pre-Christian and Christian iconographic traditions, creating an amalgamation that is both clearly Christian and yet also strikingly Sámi in every respect.

This composite symbol is mounted above the center of the three ranges of pipes, each section of which is surrounded by wooden posts suggestive of mountain peaks. The posts are ornamented with inlaid antler intarsia in the shape of long braids and stars, typical of duodji ornamentation of long handles or staffs. The organ exterior's use of native pine, birch, reindeer leather, and antler provides a markedly indigenous response to the foreign artwork behind the altar, compelling the celebrant of church services to look out upon an emphatically local and specifically Sámi artistic milieu as he faces his congregation in the pews.

Above the congregation, in the organ loft itself, the virtuoso duodji skills of Sunna become even more evident. The organ console's yellow pine exterior is accented with birch trim below the keyboard and antler along its edges. Birch is also used for the keyboard's black keys, while the white keys are carved of reindeer antler, the edge of each etched with a rhomboid 
sun motif. The stop buttons of the console's effects register are also made of birch burls, topped by oblong medallions of antler, etched to resemble small noaidi drums. Each medallion is marked with a drawing that reflects the character or nature of the effect: the stop for the organ's tinkling Zymbelstern, for instance, is marked with a star, while the stop for the delicate, melodious effect known as Vox virginea (Jungfernregel) is decorated with a drumhead depiction of Sáráhkká, the pre-Christian goddess of hearth and uterus.

Sitting at this console, the organist thus presses keys made of traditional Sámi materials and manipulates sound by means of stops that recall the noaidi drums confiscated and burned by church authorities centuries earlier. The stand that holds the organist's music is shaped to recall a Sámi njiskun (njuikon) heddle, suggesting that playing is a type of musical weaving, producing bands of beautiful melody in the air above the congregation (Boström 1998, 79).

In the context of a church décor, Sunna's work produces an aesthetically pleasing yet defiant assertion of cultural continuity, deployed in response to the dominant discourse of rupture inherent in Christian portrayals of conversion. His images suggest a syncretism or union of religious outlooks that his own Laestadian community would consciously reject. Yet, noted Sunna, the community did not openly criticize his work. 'Really', he notes in regard to the congregation's reception of his art, 'after this many centuries, the old nature religion is practically in our genes.' Sunna's decoration of the organ asserts a nonnegotiable Sámi heritage, one which must be simply acknowledged as part of the cultural and spiritual background brought to the pews by the church's faithful.

\section{'Noaiddilatnja/Nåjdens sal'}

In the year 2005, a commission for the decoration of a secular space allowed Sunna to further explore his culture's pre-Christian past. Sunna was asked to ornament the doorway and interior of the largest auditorium space in Folkets hus hall in downtown Kiruna. The result was Noaiddilatnja/Nåjens sal [The Noaidi's Hall], a permanent installation that makes entering the imaginative world of the theater space akin to a journey through a noaidi's drum. On the outside of the auditorium's main door, Sunna created a conceptual drumhead of reindeer leather and wood. On it, he affixed various renderings of pre-Christian Sámi gods, depicted much as they tend to appear on the seventy-odd shamanic drums that survive from earlier centuries. Here, on the outside of the hall, Sunna has placed the male deities 
Figure 3. Outer door of Noaiddilatnja. Folkets hus, Kiruna. Photo Thomas A. DuBois.

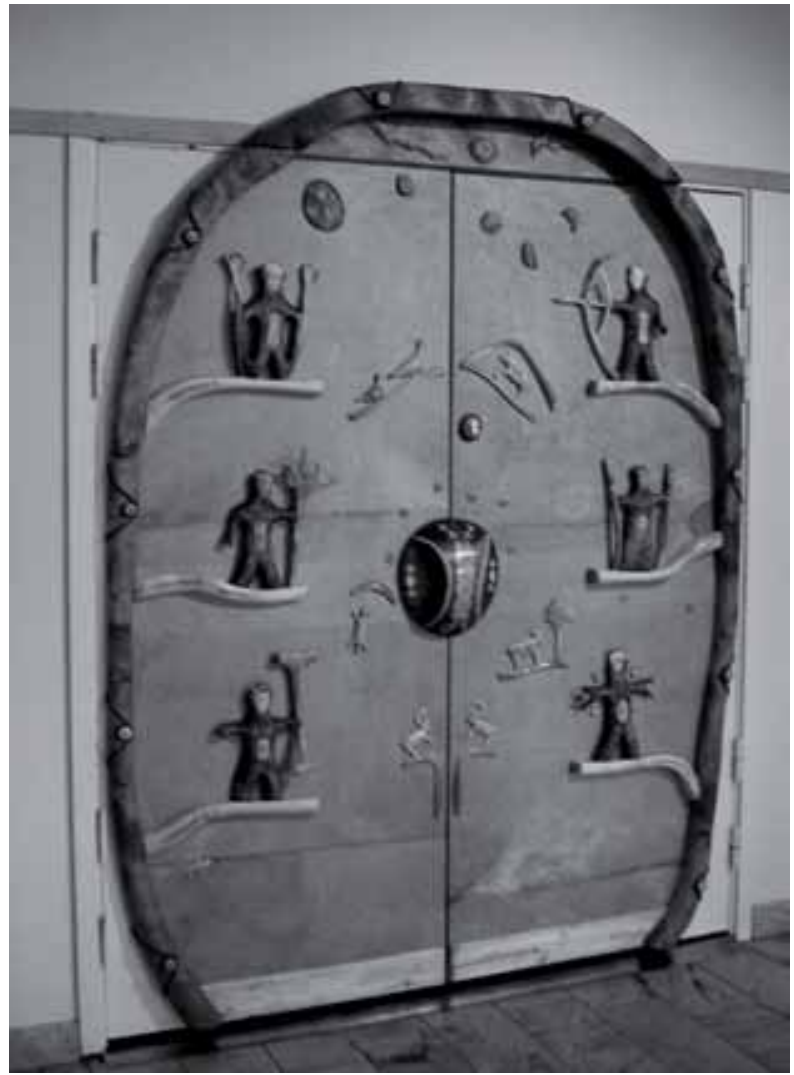

of importance to pre-Christian Sámi: Sunna's Čoarve-olmmái, for instance, the deity typically depicted holding a reindeer antler, is featured holding an appropriately large piece of actual antler. The deity's face and hair line, also, are created out of a piece of antler taken from close to its base, where the antler's smoothness gives way to hard stubble. The wooden portions, as in Sunna's earlier works, are made out of birch, carefully polished and merged with the antler pieces in techniques typical of duodji.

When one enters the hall, however, the installation's art becomes more intimate. Here, in the interior space, Sunna has placed symbols of the spirits and beings closest to Sámi in their pre-Christian domestic spirituality. There are images of the household goddesses Sáráhkká, Uksáhkká, and Juksáhkká, each placed in her own conceptual goahti hut, placed on top of an antler-inlaid birch staff. Another panel depicts the spirit helpers the noaidi was said to rely upon for spirit travel: reindeer bulls, fish, and birds. The 
moon figures as well as a sacred being. On another pole, Sunna depicts a saivo lake with its double bottom, allowing the fish to disappear periodically and providing an opening to underworlds for the noaidi to enter. And again there is the sun, lovingly rendered, spreading its warming rays to make the earth inhabitable and to warm its descendents, the Sámi. On the stage of the auditorium, to the right of the audience's main focus of attention, Sunna placed a sieidi idol and drum. Coming to Najjdens sal for cultural events or entertainment becomes, in Sunna's installation, parallel to the central and cherished spiritual ceremonies of pre-Christian Sámi: a time for communal sharing and union in the contemplation of the divine.

\section{'Duološin Aggalačči: från forntid till evighet'}

The experience of creating this installation prepared Sunna for an even more challenging undertaking: an art installation that would chronicle the meeting of the pre-Christian and Christian faiths in Sámi history. Sunna's 2005 'Duološin Aggalačči: från forntid till evighet' [From Antiquity to Eternity] seeks to depict this religious meeting in respectful and evocative manner. Sunna calls it 'an artistic journey to the world of the senses'. In an accompanying $\mathrm{CD}$ that features an interview with Sunna describing his work, he states:

Figure 4. Duološin Aggalačči: från forntid till evighet. Image courtesy Lars Levi Sunna.

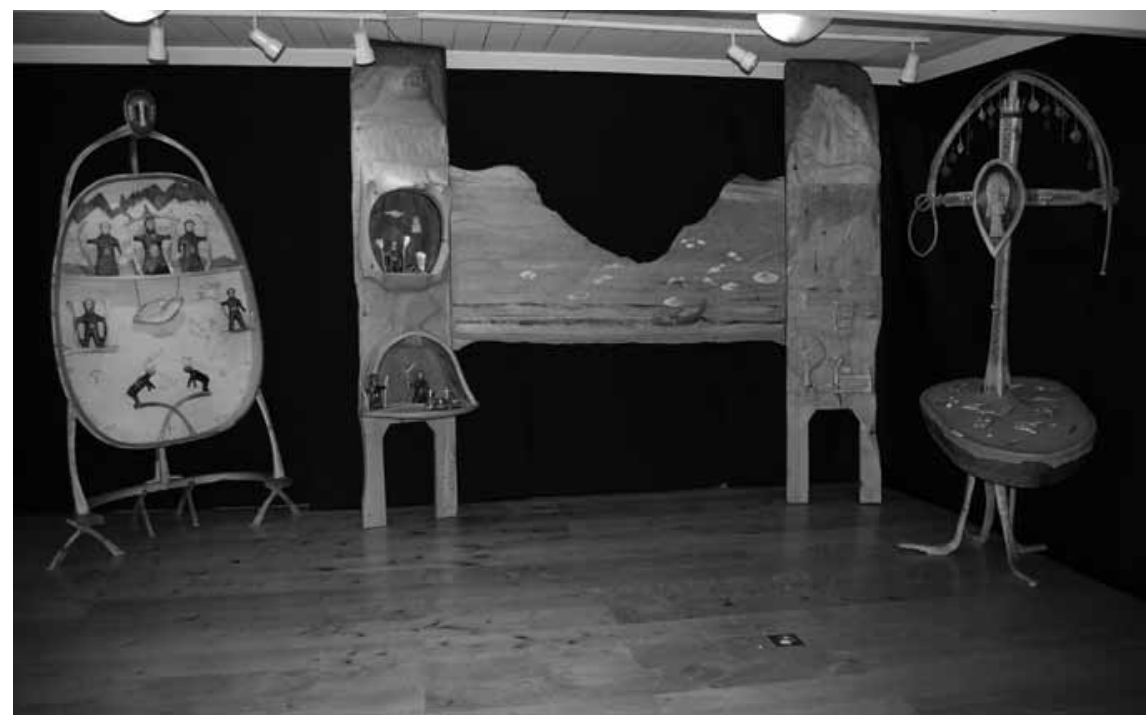


I wanted to show what happened in the meeting between Christianity and the old Sámi nature religion. There is a harmony which occurs in which we must respect each other and meet for discussion.

The fifteen-minute CD narration explains the symbolism of the figures included in the assemblage and clarifies their meaning in Sunna's own words. Sunna has also taken the installation to various places in Sweden and Norway to display and explain it, including, of course, his home church at Jukkasjärvi as well as other churches and public halls throughout the region.

In contrast to many of his past commissions, Sunna conceived of his installation and its theme before securing any funding for it. In an interview with Patrik Boström (2008), Sunna recounted the vicissitudes of his hunt for the material resources to undertake this ambitious project. He applied to a wide array of art institutions but received, as he recalls it, usually the same reply: they viewed the project as well thought-out but lying outside of their funding criteria. Its openly religious theme and potentially provocative juxtaposition of pre-Christian and Christian Sámi religiosity perhaps rendered the proposed work too daring for the highly secularized art world of contemporary Sweden. Likewise, the project could not be viewed in any way as duodji, since it promised to continue on Sunna's path toward the visual arts. Lars Levi had nearly abandoned the project as unrealizable when, as a last attempt, he sent a description to Bishop Rune Backlund, bishop of Luleå. Backlund had a long history of support for Sámi endeavors, including the production of a fresh translation of the New Testament into Lule Sámi, which appeared in 2004, during his time as chairman of the Swedish Bible Society. He also had missionary experience in Ethiopia, and intimate knowledge of the Swedish church's missionary efforts more broadly in East Africa and the Middle East. Backlund responded favorably to Sunna's letter, and offered to finance the project's materials. In all, Sunna estimates that the project cost some six hundred thousand Swedish crowns, the bulk of which was financed through a grant from the Church of Sweden.

Sunna states that a journey requires a vehicle, and the vehicle at the center of his work is a Sámi sledge, packed with a noaidi drum and its attendant spirits and deities. At the top, beneath the Northern Lights, he places the three female deities, Maddaráhkká, Juksáhkká, and Sáráhkká. Elsewhere in the work he also includes Uksáhkká, the guardian of the doorway, as she welcomes the Christian Eucharist to the goahti. Below these figures, Sunna places two male deities, Bieggolmmái, the deity of wind and weather, whom Sunna portrays as both sometimes fierce and at other times warm 
and greeting. There is also Leaib-olmmái, a deity of hunting luck, holding an elm bough. This drum, Sunna recounts, was handled by the noaidi, who could use it to travel the cosmos. Sunna retells a legend of the meeting of an old noaidi with Lars Levi Læstadius, in which the minister challenged his counterpart to use his ability to journey by spirit to retrieve Læstadius' cooking pot from back on the coast. According to the legend, when Læstadius rises the next morning to perform his morning prayer, the pot has appeared before him with no further comment.

To the right of this drum sculpture, Sunna has created a large mountain, containing a sieidi offering site high on a slope above, and a more detailed offering site below, where Bieggolmmái recurs, here depicted receiving offerings made to him at the site. Sunna recounts how as a child he was taught never to take objects from a sieidi that had been left as offerings. He notes that his parents instilled this respect of such places despite the fact that they were Laestadian Christians.

A key image in the overall work is the depiction of the inside of a goahti, in which the goddesses Uksáhkká and the hearth goddess Sáráhkká are shown greeting the hosts and chalice of a Christian Eucharist. As Sunna recounts: 'But now a guest has come. Now Christianity is their guest. And when a guest visits, you must respect each other.' The amicable meeting of the two religions here can be seen as the ideal for which Sunna strives in his work, a conscious coming together which does not compromise the essence or significance of either.

From here, Sunna depicts further elements of travel. Reindeer herds are depicted abstractly via ear-marking diagrams, while a boat symbolizes the oarless path of the individual on the waters of life. As Sunna recounts, the boat has no oars, since one cannot decide where one's life flows. There is a rudder, however, to allow one to steer, at least sometimes. Significantly, Sunna has placed in the boat a bit of fishing net from the nets his parents used in his youth, along with a Bible verse in Sámi in which Jesus says 'Follow me and I shall make you fishers of men' (Matt. 4:19). Thus, in this single figure, Sunna merges familial experience with his Christian identity and the larger cultural journey of Sámi people from nature religion to Christianity.

On the Christian side of the installation, Sunna includes a rendering of the two gates of Christian theology. One, the narrow gate, is marked with Jesus' words, 'I am the gate, Whoever goes in through me, he shall be freed' (John 10: 9). The other, uncaptioned, wider gate is filled with the trappings of the secular world - cars, television, cell phones. 
Finally, at the right of the installation, Sunna depicts a noaidi drum, its head violently split by an enormous Cross that has grown up through it. Around the Cross Sunna depicts a Sámi lasso, symbolizing the many snares of the world, and a string of leaves, symbolizing the imperfect souls of human beings tied to the Cross by the thread of life. In Sunna's recounting, the new religion threw the old into complete chaos. We can never come back to that old nature religion, he asserts, but rather, must lift up our gaze to the light of life. The installation thus presents a narrative of the triumph of Christianity, but not without a certain nostalgia, and a good deal of respect, for the old religion it displaced.

\section{Indigenous Responses to Religious Usurpation}

In his lyrical autobiography The Way to Rainy Mountain (1969), Kiowa author N. Scott Momaday portrays his people's Christianization as a painful and culturally devastating tragedy. Recalling his grandmother's testimony of the last attempted performance of the Sun Dance, a once-central element of Kiowa ritual life, Momaday writes:

She was ten when the Kiowas came together for the last time as a living Sun Dance culture. They could find no buffalo; they had to hang an old hide from the sacred tree. Before the dance could begin, a company of soldiers rode out from Fort Sill under orders to disperse the tribe. Forbidden without cause the essential act of their faith, having seen the wild herds slaughtered and left to rot upon the ground, the Kiowas backed away from the medicine tree. That was July 20, 1890, at the great bend of the Washita. My grandmother was there. Without bitterness, and for as long as she lived, she bore a vision of deicide. (Momaday 1969, 10.)

This same sense of tragedy - of regret - at the destruction of one coherent and satisfying worldview to make way for another is palpable in many of Sunna's depictions of Sámi pre-Christian religion. He presents its beliefs, sacred spaces, and prime deities with a sense of affection as well as respect, despite his clear and fervent embrace of Christianity in his own faith life. When asked about the violent image of the sundered drum in his Duološin Aggalačči installation, Sunna claims objective neutrality, stating: 'I make no value judgments about it, but simply am describing the history as it happened' (Patrik Boström 2008). Yet he also holds up the old religion as a valuable cultural memory and resource: 'It can be an inspiration for us today' (ibid.). 
Sunna is also clear in assessing blame for the misdeeds of past missionaries and church authorities. Because the church stood as the primary organ of the Swedish state in Sámi communities for much of the seventeenth, eighteenth, and nineteenth centuries, its activities became synonymous with the repressive assimilative policies directed at the Sámi from the government. Church leaders were also sometimes virulent in their attempts to suppress the old religion and compel the Sámi to fully embrace Christianity, going so far as to have dissenters arrested and even executed. This harsh approach finds reflection, Krister Stoor (2004) argues, in Sámi legends in which a church becomes a site of attempted genocide, a place where the authorities once purportedly trapped the Sámi population and attempted to burn them alive. Stoor posits that legends about such atrocities reflect a legacy of distrust and lingering resentment among Sámi, despite the passage of time and the broader secularization of state policies toward the Sámi community. By incorporating shamanic drum imagery into the ornamentation of the Jukkasjärvi church, Sunna pointedly reminds his knowledgeable viewers of the past injustice that led to the confiscation and destruction of Sámi drums, a destruction that, in small measure, he helped to reverse through the creation of modern drums during his earlier duodji career. Ulf Boström records an interview with the artist at the time of the organ's completion that clearly encapsulates this pronouncement of culpability:

[Sunna:] Some sort of redress is needed.

[Boström:] I wonder what he means by 'redress'. How should it proceed? Some sort of apology in which the church officially asked forgiveness for the injustices done to the Sámi through history?

Lars Levi Sunna thinks for a moment and then replies, 'Yes, that would do'. (Ulf Boström 1998, 81.)

The Swedish Lutheran church did indeed make such a formal apology several years later, an act which reflects a broader recognition of the failure of the church in the past to uphold Christian ideals when confronting religious diversity. In discussing Bishop Rune Backlund's generous funding which made the 2005 Duološin Aggalačči project possible, Sunna further notes:

I like to call it a kind of letter of indulgence. The church has asked forgiveness for its actions against the Sámi and when Backlund supported this project with money it was a concrete act of restitution for the forgiveness of sins. (Patrik Boström 2008.) 
Acknowledging the injustices and psychological distress of the missionization process or the church's former collusion with state authorities in the work of suppressing Sámi culture and expressions, does not mean, however, that Sunna seeks a return to the pre-Christian belief system he so warmly and skillfully depicts. Sunna states as much clearly, albeit with a certain sense of nostalgia: 'We have only fragments left of the old nature religion and it is impossible to truly return to it because of the way we live today' (Patrik Boström 2008). Rather, Sunna seems to call for a simple acknowledgement of the former effectiveness and meaningfulness of the old religion and its practitioners, much as Sergei Kan (1991) notes in his examination of contemporary Christian Tlingit memories of past shamans and shamanism in modern Alaska. Kan's informants, all active Christians, generally refused to castigate past shamans, stressing instead the social and spiritual value of the old religion, and often seeking to draw parallels between the workings of the old belief system and that of modern Christianity or psychotherapy. In the narratives offered by Kan's informants, past shamans were not evil or misguided: rather, they were effective advocates for their communities in the spirit world, essential sources of spiritual guidance and healing before the arrival of Christianity. The fact that Christianity eventually replaced them does not lessen the importance or value of this past role.

In its rejection of the old religion as a viable modern alternative to Christianity, Sunna's work differs markedly from the kinds of religious syncretism chronicled in Håkan Rydving's (1995) important study of seventeenth and eighteenth century religious change among Lule Sámi. Rydving depicts an era in which Sámi consciously sought to maintain both the old religion and the new alongside each other, resisting clerical efforts to do away with the old deities or practices through a strategy of underreporting and avoidance. Parallel rituals, particularly at key life-cycle events such as baptism, allowed Sámi to maintain both outwardly Christian / covertly pre-Christian identities in a context in which the latter was harshly proscribed. In examining pre-Christian ritual continuities among newly converted Santal Catholics in India, Selva J. Raj (2007) notes similar strategies of covert maintenance, motivated by the continued social importance of non-Christian puberty rituals among the Santal community. Although converted Santal willingly undergo a Christian confirmation ceremony as a replacement of their culture's earlier rituals at village sacred groves, they nonetheless also participate in the non-Christian ceremony as well, thereby acquiring the adult status and social mobility that would otherwise be lost to them within the larger Santal society. They are able to do so in part by claiming to Christian 
clergy that the pre-Christian rituals are merely customary practices that do not represent their religious convictions. Chibueze Udeani (2007) points to similar phenomena and discourse among African convert communities, especially in connection with coming of age rituals. Stressing the largely unstated conflicts behind such twinned rituals, particularly as related to the Santal sacred grove, Raj (2007) writes:

Indeed, the history of many religious traditions amply shows that sacred sites are not merely sites of religious rituals and devotion. More often than not, they are also sites of conflicting discourses, contested identities, and competing rivalry for leadership and power.

By bringing pre-Christian images into Christian worship spaces, as well as into public places important to the Sámi community of his locale, Sunna seeks to acknowledge this past conflict as a historical fact and enduring cultural memory, although not as an attempt to displace Christianity as his community's faith.

On another level, however, Sunna's artistic interventions can also be regarded as instances of inculturation, the infusion of culture-specific expressions into the workings and material culture of a community's Christian worship (Holmes 1999; Magesa 2004; Udeani 2007; Olson 2009). In describing inculturation as a natural and laudatory development, Pope John Paul II defined the phenomenon as 'the intimate transformation of authentic cultural values through their integration in Christianity and the insertion of Christianity in the various human cultures' (1990). As such, inculturation is conceived as a balanced interfertilization, rather than the one-sided loss and replacement of cultural traits implied in the process of acculturation. It can be unconscious and inevitable - as is evident in any examination of the European cultural traits that have come to shape modern European Christianities as well as colonial transplantations (Olson 2009). But it can also be potentially intentional, as when modern liturgists or artists endeavor to insert elements of a community's previous religious system into their Christian worship. At its most idealized in contemporary Christian theology, this interfertilization can be viewed as a celebration of cultural diversity as an essential gift of God: i.e., rather than seeing differences in culture and language as a post-Babel mark of human folly and ambition, the specificities of human cultures become riches to be valorized and incorporated into Christian liturgy. Inculturation has been strongly embraced in liberal Lutheran circles, particularly in connection with missionary activities that 
many secular Swedes view as negative holdovers from the colonial past. From this perspective, it is understandable that church authorities would welcome the expressions of Sámi tradition and culture which Sunna's work makes palpable in the churches of northern Sweden.

Inculturation is, however, a potentially divisive process, one that may pit more estranged members of a church community against those who strongly identify with the official church's received norms and practices. Culturally accented rituals and adaptations may sometimes find harsh rejection among rank-and-file church members, regardless of whether they have gained clerical support. Issues often arise when the elements of culture to be incorporated are seen to directly contradict elements of official dogma or strictures regarding liturgy or worship space. When explicitly pre-Christian rituals are brought into the church, for instance - as in the case of smudge ceremonies introduced into a Catholic mass in the context of the Kateri Tekakwitha Conference (New York Times 1992; Holmes 1999) - the act may prove as likely to spawn conflict and discord as unity. Sunna downplays any such conflicts resulting from his own works, although acknowledging that the installations can be challenging both for Christian and non-Christian viewers. In a Sámi context that seeks to prevent outright conflict through indirection and avoidance, silence does not necessarily imply consent, nor is it certain that the more strident elements of Sunna's critiques are uniformly embraced by the community. Whatever the case, however, Sunna's works are today a part of the Sámi community's overt discourse concerning Christianity and its place in Sámi culture.

On November 7, 2007, the League of Swedish Church Congregations (Svenska kyrkans församlingsförbund) presented Lars Levi Sunna with an award in recognition of having made 'significant contributions in the areas of Sámi culture and church art' (Engvall 2007). Clearly, the Swedish state church has valued his dual message of restitution and inculturation: of acknowledging the past traumas of the Sámi missionization and intentionally importing elements of past Sámi religiosity into contemporary Sámi Christian worship space. At the same time, as with Native American instantiations of acknowledgement and inculturation, such attempts can spur contradictions and conflicts. As Marie-Therese Archambault, a Hunkpapa Lakota woman and Franciscan nun stated in 1992 in describing her own views of her Catholic faith: 'As a Native Catholic, the very faith you embrace is one that used to destroy you, that collaborated with the government in cultural genocide' (New York Times 1992). Finding a way to both acknowledge this fact - this historical rupture in the fabric of an ancient belief system - and 
the beauty or value of the new belief system requires more than history, or theology, or altered church regulations: in Lars Levi Sunna's view, it requires art. And that is what Sunna has attempted to provide in his various contributions to the cultural life of contemporary Sápmi.

Bibliography

Ahlbäck, Tore (ed.)

1987 Saami Religion: Based on Papers Read at the Symposium on Saami Religion held at Abo, Finland, on the 16th-18th of August 1984. (Scripta Instituti Donneriani Aboensis XII.) Stockholm: Almqvist \& Wiksell International.

\section{Ahlbäck, Tore \& Jan Bergman (eds)}

1991 The Saami Shaman Drum. Based on Papers Read at the Symposium on the Saami Shaman Drum held at Åbo, Finland, on the 19th-20th of August 1988. Ảbo: Donner Institute for Research in Religious and Cultural History.

\section{Boström, Ulf}

1998 Lars Levi Sunna - Frå bygd til vildmark 1997-98. Luleå stifts årbok, 75-81. Luleå: Luleås stift.

\section{Boström, Patrik}

2008 Från trotill renskötsel.-Norrländska Socialdemokraten, December3.<http:// www.nsd.se//NYHETER/ARTIKEL.ASPX?ArticleID=4225010>

\section{Bäckman, Louise}

1975 Sájva: Föreställningar om hjälp- och skyddsväsen i heliga fjäll bland samerna. Stockholm: Almqvist \& Wiksell International.

\section{Engvall, Urban}

2007 Kulturpris till Lars Levi Sunna. - svenskakyrkan.se. <http://www. svenskakyrkan.se/default.aspx?id=627983>

Holmes, Paula Elizabeth

1999 'We are Native Catholics': Inculturation and the Tekakwitha Conference. - Studies in Religion/Sciences religieuses 28 (1), 153-74.

\section{Johannes Paulus II}

1990 Redemptoris Missio: On the Permanent Validity of the Church's Missionary Mandate. <http://www.vatican.va/edocs/ENG0219/_INDEX.HTM> 


\section{Kan, Sergei}

1991 Shamanism and Christianity: Modern-Day Tlingit Elders Look at the Past. - Ethnohistory 38 (4), 363-87.

\section{Kihlberg, Kurt}

1999 Giehta Dáidu: Den stora boken om samernas slöjd. [The Great Book of Sami Handicraft] Rosvik: Förlagshuset Nordkalotten.

2003 Duodji-slöjdens mästare: En bok om den magiska sameslöjden. [Masters of Sami Handicraft: A Book about the Magic Sami Handicraft.] Rosvik: Förlagshuset Nordkalotten.

\section{Lehtola, Veli-Pekka}

2004 The Sámi People: Traditions in Transition. Aanaar-Inari: Kustannus Puntsi.

\section{Lundmark, Bo}

1982 Bæi'vi Mánno Nástit. Sol- och månkult samt astrala och celesta föreställningar bland samerna. (Acta Bothniensia Occidentalis. Skrifter i västerbottnisk kulturhistoria). Umeå: Västerbottens museum.

1985 'They consider the sun to be a mother to all living creatures': The SunCult of the Saamis. - Louise Bäckman \& Åke Hultkrantz (eds), Saami Pre-Christian Religion: Studies on the Oldest Traces of Religion among the Saamis, 179-88. (Acta Universitatis Stockholmiensis. Stockholm Studies in Comparative Religion 25.) Stockholm: Almqvist \& Wiksell International.

\section{Magesa, Laurenti}

2004 Anatomy of Inculturation: Transforming the Church in Africa. Maryknoll, NY: Orbis Books.

\section{Manker, Ernst}

1938 Die lappische Zaubertrommel: Eine ethnologische Monographie I. (Acta Lapponica I.) Stockholm: Thule.

1947 De svenska fjälllapparna. (STF:s handböcker om det svenska fjället 4.) Stockholm: Svenska turistföreningens förlag.

1950 Die lappische Zaubertrommel: Eine ethnologische Monographie II. (Acta Lapponica IV.) Stockholm: Gebers.

\section{Momaday, N. Scott}

1969 The Way to Rainy Mountain. Albuquerque: University of New Mexico Press.

\section{New York Times}

1992 Catholic Indians Try to Reconcile Two Traditions. New York Times, August 17, 1992. <http://query.nytimes.com/gst/fullpage.html?res=9 E0CE4D7153CF934A2575BC0A964958260> 


\section{Olson, Joseph}

2009 Jesuit Inculturation in the New World: Experiments in Missions of Sixteenth, Seventeenth, and Eighteenth Centuries. Anchorage, AK: Outskirts Press.

\section{Outakoski, Nilla}

1991 Lars Levi Laestadiuksen saarnojen maahiskuva: Verrattuna Kaaresuvannon nomadien maahiskäsityksiin. Oulu: Oulun Historiaseura.

\section{Rydving, Håkan}

1995 The End of Drum-Time: Religious Change among the Lule Saami, 1670s1740s. 2nd ed. Uppsala: Almqvist \& Wiksell.

\section{Raj, Selva J.}

2007 The Santal Sacred Grove and Catholic Inculturation. - Journal of Ecumenical Studies 42 (2), 243-52.

\section{Stoor, Krister}

2004 Bakhållet vid Lappskottbacken. En berättelse om 'de främmande' i en samisk miljö. - Jurij Kusmenko (ed.), The Sámi and the Scandinavians. Aspects of 2000 years of contact, 73-88. (Schriften zur Kulturwissenschaft Band 55.) Hamburg: Verlag Dr. Kovac.

\section{Sunna, Lars Levi}

1998 Skulpturer. - Frå bygd til vildmark 1997-98. Luleå stifts årbok, 82-9. Luleå: Luleås stift.

\section{Undeani, Chibueze}

2007 Inculturation as Dialogue:Igbo Culture and the Message of Christ. Amsterdam and New York: Editions Rodopi. 